\title{
Potentially toxic dinoflagellates in Mediterranean waters (Sicily) and related hydrobiological conditions
}

\author{
M. G. Giacobbe ${ }^{1}$, F. Oliva ${ }^{2}$, R. La Ferla ${ }^{1}$, A. Puglisi ${ }^{2}$, E. Crisafi ${ }^{1}$, G. Maimone ${ }^{1}$ \\ ${ }^{1}$ Istituto Sperimentale Talassografico, CNR - Sp. San Raineri, I-98122 Messina, Italy \\ ${ }^{2}$ CEOM - Centro Oceanologico Mediterraneo, Palermo, Italy
}

\begin{abstract}
The seasonal occurrence of 3 potentially toxic dinoflagellates in different coastal environments of Sicily (Mediterranean Sea) and the associated hydrobiological conditions are reported. Dinophysis sacculus and Alexandrium sp. occurred, in 1993, in shallow inland waters (a brackish lagoon of the Tyrrhenian Sea), characterized by thermo-haline homogeneity. The densities of Dinophysis were maximal in April, when the waters were depleted in nutrients, the N:P ratio was 10:1 and the algal population, including synechoccoid cyanobacteria, bloomed. Afterwards, the cell concentrations decreased and in summer there was a total replacement of Dinophysis with Alexandrium. In late summer 1993 , Gymnodinium catenatum was also recorded in offshore waters of the Malta Channel, during coastal upwelling associated with thermal stratification of the waters and the cells dispersed shorewards. DSP toxicity of blue mussels was detected in April, at a low level only, in the area affected by $D$. sacculus. No data is, however, available to date on PSP production by Alexandrium and G. catenatum, which are new records for these areas.
\end{abstract}

KEY WORDS: Dinoflagellates · Hydrobiological factors - Mediterranean Sea - Shellfish contamination

\section{INTRODUCTION}

In recent years, various species of both naked and armoured dinoflagellates which produce biotoxins have been recorded from diverse geographical areas (e.g. Anderson 1989, Maestrini 1991). Numerous studies have shown that blooms of harmful dinoflagellates are often closely related to changes in the structure of the water column, such as decreased turbulence and development of thermal or haline stratification (e.g. Delgado et al. 1990, Delmas et al. 1992), although no water column stratification has been observed in coincidence with blooms in Spanish Atlantic waters (Fraga et al. 1988).

Recently, the occurrence both of Dinophysis species and Alexandrium minutum, potential producers of DSP and PSP toxins, respectively (Diarrhetic and Paralysing Shellfish Poisons), has been reported from brackish environments of Sicily (Giacobbe et al. 1991, Giacobbe \& Maimone 1994) where both exploitation of shellfish from natural banks and aquaculture are prac- tised, as well as in other areas of the Tyrrhenian coastline, where artificial reefs and pilot plants for shellfish farming are located (Giacobbe et al. 1993). In 1993, Dinophysis sacculus Stein was again found in a confined Tyrrhenian site, where it co-existed with a species of Alexandrium Halim. Gymnodinium catenatum Graham was also recorded, for the first time, in an area of the southern coastline where upwelling of intermediate waters and their shoreward advection occur in summer (Magazzù 1988).

The present paper analyses the spring-summer changes in densities of these dinoflagellates, in relation to hydrobiological conditions.

\section{MATERIALS AND METHODS}

Two sites on the Sicilian coastline were investigated in 1993 (Fig. 1). The first was Green Lake (Oliveri-Tindari), a brackish Tyrrhenian lagoon not directly linked, by means of canals or otherwise, to the neighbouring 


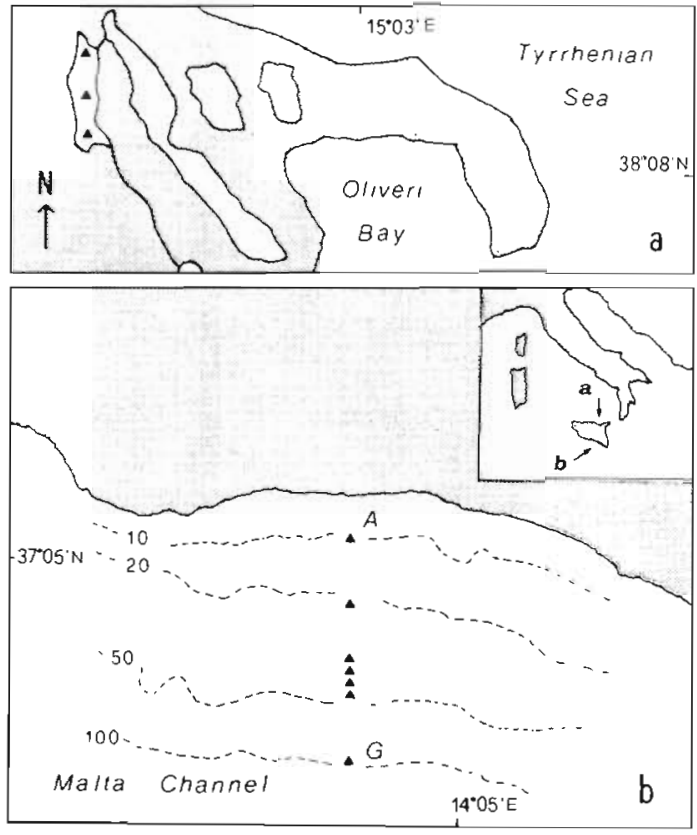

Fig. 1. Map of (a) the Oliveri-Tindari area and (b) the Malta Channel with sampling stations

sea. The area is subject, however, to seawater inoculation during storms, as well as to continental influence - through water bearing inflows - green discolouration of the waters and anoxic events (Giacobbe et al. 1992). Samplings were made monthly, from March to September, at the subsurface $(0.2 \mathrm{~m})$ and near-bed layer $(2.0$ to $3.0 \mathrm{~m})$ at 3 stations. The second site was an area of the southern coastline (Gulf of Gela, Malta Channel). A transect from inshore to offshore waters ( 7 stations) was sampled in March and September, at the subsurface layer $(0.5 \mathrm{~m})$ and at 3 or 4 points of the water column (from 0.5 to $50 \mathrm{~m}$ ).

Water samples were taken by Go-Flow Niskin bottles (General Oceanics) and subsamples, preserved with glutaraldehyde ( $2 \%)$, were settled and examined by inverted microscope (Axiovert 35-Zeiss) for the counts and identification of algal taxa. Direct cell counts of picoalgae, ascribed to synechoccoid cyanobacteria, were made according to La Ferla \& Crisafi (1991).

Temperature and salinity measurements were made by reversing thermometers, fitted to the sampling bottles, and by a $8400 \mathrm{~A}$ Autosal inductive salinometer, Guildline Instr. Ltd (Millero \& Poisson 1981), respectively. Samples for macronutrients were analysed according to Strickland \& Parsons (1972) - except for ammonia (Aminot \& Chaussepied 1983) - and the concentrations were measured using a Lambda 3 Perkin-Elmer spectrophotometer; the total concentration of nitrate, nitrite and ammonium is reported here as DIN (dissolved inorganic nitrogen). N:P atomic ratios were calculated as DIN:SRP (soluble reactive phosphate). Chlorophyll a concentration was determined after overnight extraction with acetone (90\%) (Holm-Hansen et al. 1965) and fluorescence analysis by a F-2000 Hitachi spectrofluorometer.

Shellfish Mytilus galloprovincialis, which are primary transvectors of algal toxins, were introduced as bioassay organisms into Green Lake, where high concentrations of Dinophysis sacculus have been recorded since April 1988 (Giacobbe \& Maimone 1991). A total of 200 individuals were placed at $1 \mathrm{~m}$ depth in a net hanging from floats, at the central sampling point; the collection of specimens (20 individuals randomly gathered) was initiated 1 wk later (March 23) in coincidence with water samplings, at monthly intervals. Following the analytical procedure of UBE Ltd Research Laboratories (Tokyo, Japan), $3 \mathrm{~g}$ of midguts was homogenized ( $2 \mathrm{~min}$ ) with $15 \mathrm{ml}$ of $90 \%$ aqueous methanol solution and centrifuged at $3000 \mathrm{rpm}$ for $10 \mathrm{~min}$. The supernatant was diluted with deionized distilled water (1:1) and $50 \mu \mathrm{l}$ was placed in immunoplates for the competitive inhibition ELISA assay, using monoclonal antibodies with high specificity against okadaic acid (Usagawa et al. 1989), a component of the DSP complex. Contents of midguts were also examined microscopically for the presence of Dinophysis cells.

\section{RESULTS AND DISCUSSION}

\section{Dinophysis sacculus and Alexandrium sp.: quantitative changes and associated hydrobiological conditions (inland Tyrrhenian waters)}

Fig. 2a shows monthly variations, from March to September, of the densities of Dinophysis sacculus Stein in the innermost area of Oliveri-Tindari. The cell concentrations were maximal in April, in the upper waters $\left(\bar{X}=8000 \mathrm{l}^{-1}\right)$ and declined in the subsequent months, ending in total cell disappearance in July and August; D. sacculus, which often dominated over a small-sized Dinophysis sp., occurred again in September with average values of 1800 to 2350 cells $1^{-1}$

The experimental contamination of blue mussels showed a weak toxicity of the shellfish in April only. However, the presence in the mussel guts of Dinophysis cells ( $D$. sacculus only), or empty thecae, was confirmed through the microscopical analysis of the gut contents - except in July and August, when no cells occurred in the waters at all. These findings suggest a low production of okadaic acid by this strain. $D$. sacculus has been previously associated with DSP intoxications in the Adriatic Sea (Boni et al. 1992), but a major mussel toxicity occurred when $D$. fortii dominated over the other species 


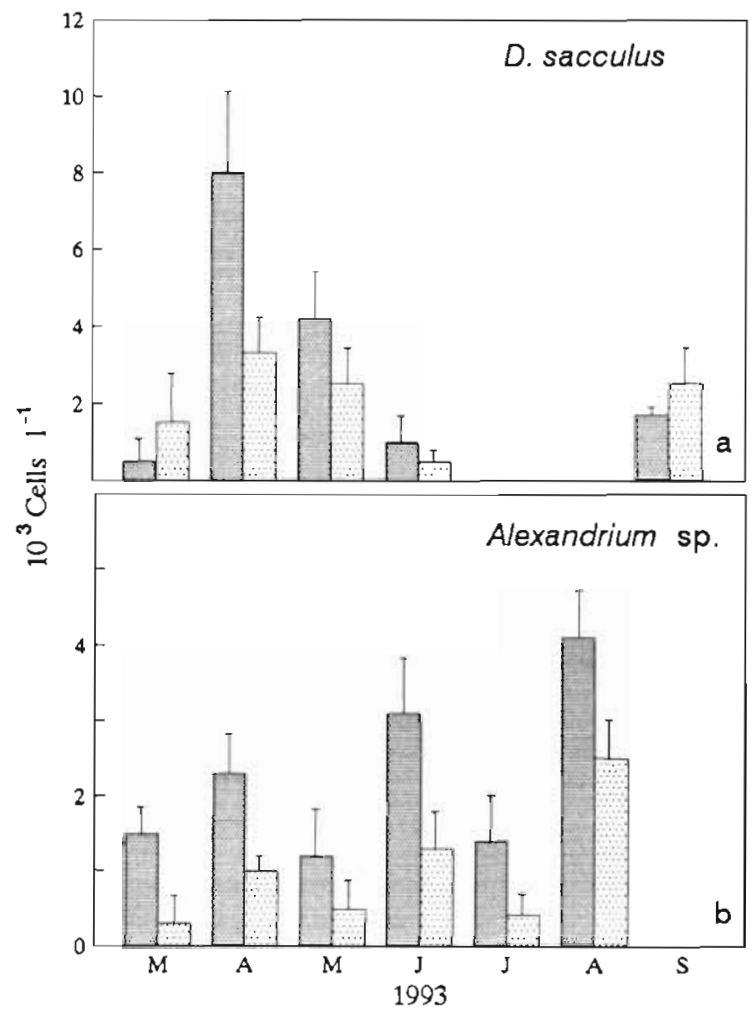

Fig. 2. Spring-summer changes in abundance of Dinophysis sacculus and Alexandrium sp. in inland Tyrrhenian waters (Oliveri-Tindari). Bars represent averages of the 3 stations. Dark bars: sub-surface; dotted bars: near-bed layer; error bar $=$ standard error of the mean (SEM) tidal currents, the water column was well mixed (Fig. 3a), unlike other Tyrrhenian lagoons (Acosta Pomar et al. 1988). Temperatures ranged between a minimum of $15.4^{\circ} \mathrm{C}$ in March, and a maximum of $25.9^{\circ} \mathrm{C}$ in June, and the salinity values from $20.7 \mathrm{ppt}$ in April, to $26.3 \mathrm{ppt}$ in September.

As shown in Fig. 3b to f, in April - when the densities of Dinophysis sacculus were maximal - concentrations of inorganic nutrients were reduced, the N:P atomic ratios did not exceed 10:1 and algal blooms developed (total phytoplankton and chlorophyll $a$ at the subsurface: $1.4 \times 10^{6}$ cells $1^{-1}$ and $5.0 \mathrm{mg} \mathrm{m}^{-3}$, respectively). During this period, the densities of synechoccoid cyanobacteria also increased, mostly in the subsurface layer, reaching a maximum in May $\left(8 \times 10^{6}\right.$ cells $\mathbf{l}^{-1}$ ).

Experimental studies by Ishimaru (1988) showed that cells of Synechococcus-type cyanobacteria and cryptomonads are consumed by Dinophysis fortii and D. acuminata, resulting in an orange or orange-red fluorescence of Dinophysis cells, probably due to residual ingested chloroplasts. Although no data are available on the nutritional requirements of $D$. sacculus, our data show that high densities of this species corresponded to high availability of Synechococcus, whereas its disappearance (July-August) coincided with a decrease in synechoccoid cyanobacteria density. However, beyond this observation, no obvious relationship was found between the two. Neither were there significant correlations between Dinophysis density and inorganic
In spring and summer, an armoured dinoflagellate co-existed with Dinophysis; both the plate morphology and the tabulation were typical of the genus Alexandrium Halim (Balech 1985), which includes most of the saxitoxin-producing species (Taylor 1992). No data are, however, available to date on the PSP production by the strains occurring in the area. Alexandrium sp. was recorded for the first time and occurred in all the sampling periods, except for September; cell density was higher in the upper waters (Fig. 2b) and peaked in summer (August: $\bar{x}=4080$ cells $l^{-1}$ at the subsurface).

Because of the shallowness of the waters (max. depth: $3 \mathrm{~m}$ ) and the wind-driven and

Fig. 3. Temporal changes of hydrobiological parameters in shallow brackish waters (Tyrrhenian Sea). (a) Temperature and salinity; (b) DIN; (c) N:P ratio; (d) Synechococcus; (e) total phytoplankton; (f) chlorophyll a. Points represent averages of the stations. Error bars = SEM. (o) Surface; $(\bullet)$ near-bed layer

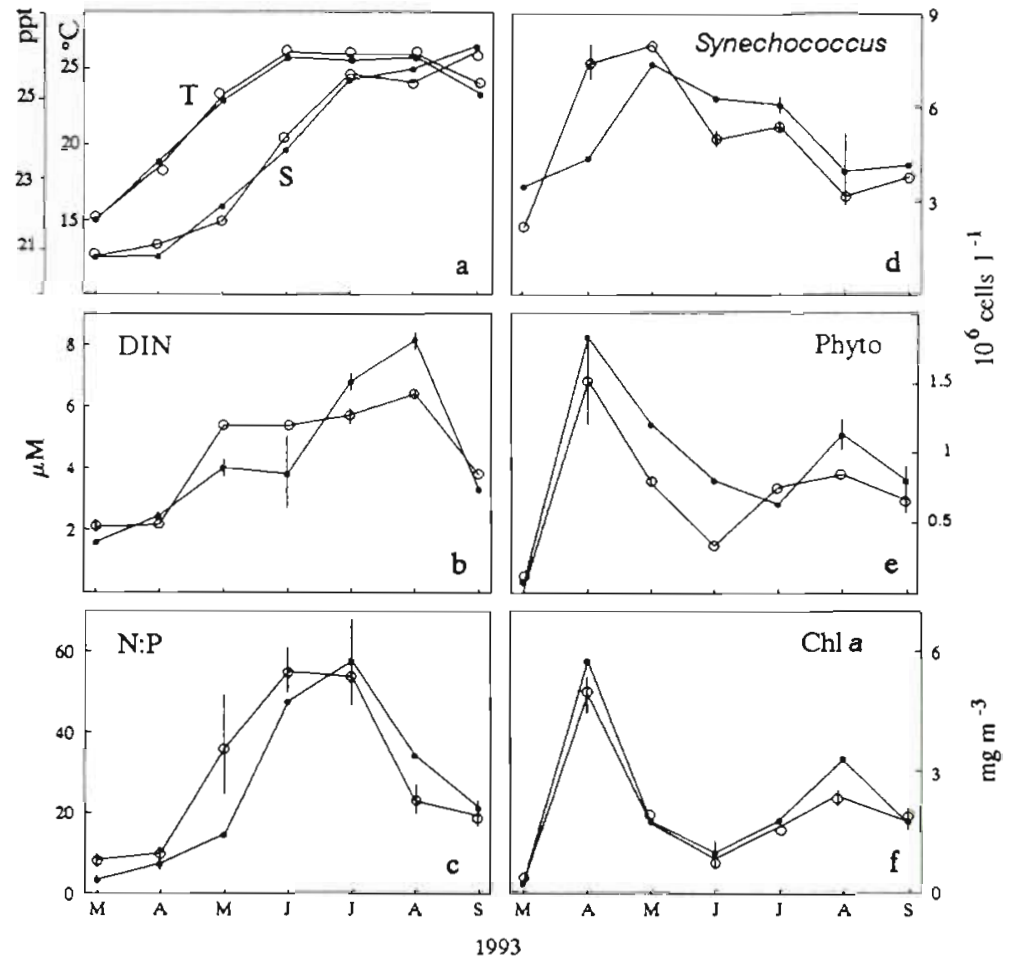




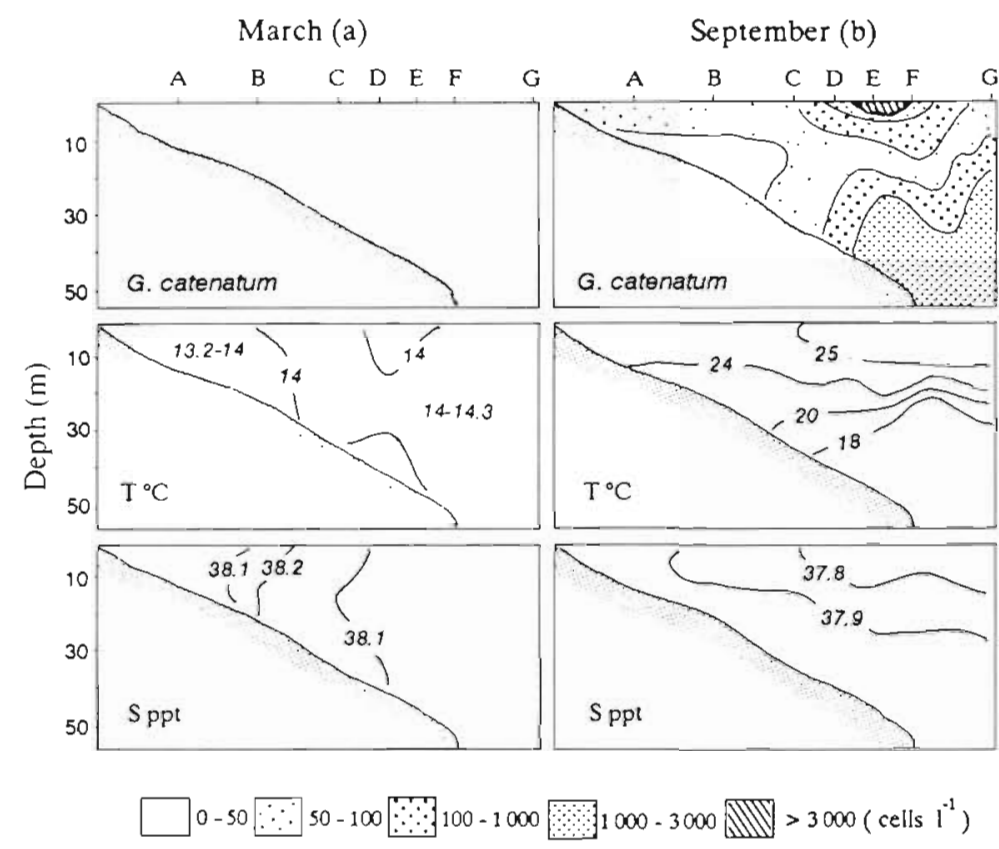

Fig. 4. Cell densities of Gymnodinium catenatum and thermo-haline structure of the waters in the Malta Channel in March and September
(Fig. 5a). Two-celled chains and single cells were recorded, for the first time, in September coinciding with thermal stratification. Abundance was highest offshore (max: 5400 cells $1^{-1}$. Stn E, $0.5 \mathrm{~m} ; 1000$ to 3000 cells $1^{-1}, 25$ to $50 \mathrm{~m}$ ) and decreased shorewards (Fig. 4b). No data on the PSP production are available yet, but similar cell concentrations in waters of the Spanish Mediterranean coast corresponded to toxicity levels of $200 \mu \mathrm{g}$ saxitoxin $/ 100 \mathrm{~g}$ clams (Bravo et al. 1990).

In September, the thermal stratification of the water involved the whole area (Fig. 4b) and a thermocline was established offshore (Stns E and F). At these stations, the upper waters were warm and well mixed ( $\mathrm{T}=$ $25^{\circ} \mathrm{C}$ ) and separated from a homogeneously cool deep layer $\left(\mathrm{T}=18^{\circ} \mathrm{C}\right.$ ) by a sharp thermocline. A slightly positive haline gradient was also observed with the increasing depth (from 37.80 to $37.92 \mathrm{ppt}$ ) (Fig. 4b). During September, there was a minor algal biomass and the highest DIN and SRP amounts were found shorewards and in the

nutrient concentration. This is in agreement with studies from French Atlantic waters (e.g. Delmas et al. 1992) where, however, cell numbers increased during marked thermal stratification of the waters. In contrast, we observed, for the whole of the period of Dinophysis presence, a thermohaline homogeneity and, in April and May only, a slight stability of the water column in the most sheltered sector.

Finally, Dinophysis absence and Alexandrium maximal concentrations coincided, in August, with higher DIN amounts and N:P values (subsurface-nearbed layer: 6 to $8 \mu \mathrm{M}$ and 23 to 34 , respectively); phytoplankton and chlorophyll a peaked again $(0.8$ to $1.1 \times$ $10^{6}$ cells $\mathrm{l}^{-1}$ and 2.3 to $3.3 \mathrm{mg} \mathrm{m}^{-3}$ ).

\section{Gymnodinium catenatum distribution and related environmental parameters (Malta Channel)}

No cells of Gymnodinium catenatum Graham occurred in the Malta Channel in March 1993, when the waters were both isothermal and isohaline (Fig. 4a): the amounts of inorganic nutrients were low (max: $1.36 \mu \mathrm{M}$ DIN, Stn $C_{i} 0.16 \mu M$ SRP, Stn E) and the values of total chlorophyll $a$ ranged between 0.01 and $0.3 \mathrm{mg} \mathrm{m}^{-3}$

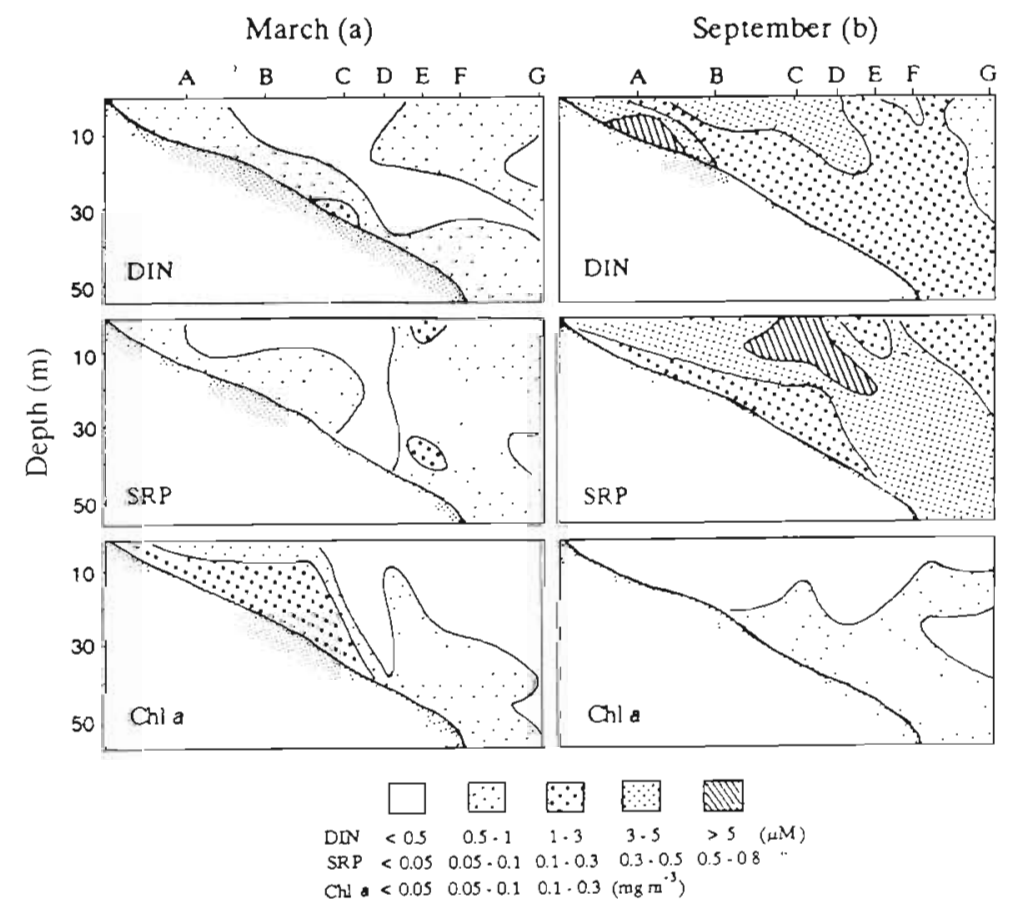

Fig. 5. Distribution of nutrients and total chlorophyll $a$ in waters of the Malta Channel 
significant inverse relationship was found, in fact, between cell densities and DIN values $(\mathrm{r}=-0.72 ; \mathrm{n}=$ $12 ; \mathrm{p}<0.01)$; the cell numbers of $G$. catenatum inversely correlated with the ammonium concentrations ( $\mathrm{r}=-0.66 ; \mathrm{n}=12 ; \mathrm{p}<0.02)$, whereas there was no correlation with nitrate or nitrite. Increases in cell numbers were also weakly associated to the decrease in the values of the $\mathrm{N}$ :P ratio $(\mathrm{r}=-0.61, \mathrm{n}=12 ; \mathrm{p}<0.05)$ which ranged, offshore, between 2 and 5 (data not shown).

\section{CONCLUSIONS}

The presence of both Dinophysis sacculus and Alexandrium sp. in the brackish Tyrrhenian area (Green Lake) may be partly attributed to an allochthonous inoculation of the cells either from the neighbouring bay, during sea storms, or from the nearby lagoons, during spring tides, when they are subject to water exchanges. The possibility of a locally initiated growth cannot, however, be excluded and further data are necessary from the adjacent waters and on the possible presence of Alexandrium hypnozygotes in the surface sediments.

In the Malta Channel, the late summer occurrence of Gymnodinium catenatum corresponded to the upwelling of cold intermediate waters and to thermal stratification. Blooms of $G$. catenatum have been recorded in the rias of NW Spain as well; their development strongly depended, in late summer, on the relaxation of upwelling and bloom prediction indices have been established (Fraga et al. 1990). This dinoflagellate, which may form long chains (e.g. Estrada et al. 1984), occurred in 2-celled chains and as a single form, suggested by other authors as indicative of suboptimal growth conditions (e.g. Blackburn et al. 1989). However, further studies in this area, as well as in mariculture sites of Sicily, are needed to clarify the allochthonous or autochthonous origin of these dinoflagellates, the mechanisms of bloom formation and factors regulating toxicity

Acknowledgements. We thank Prof. V. Bruni (University of Messina) for the useful suggestions, the reviewers for their criticism, Dr L. Walker (B.A. British College, Messina) for contributing with the English revision and A. Cosenza for his cooperation with graphs.

\section{LITERATURE CITED}

Acosta Pomar L, Bruni V, Decembrini F, Giuffrè G, Maugeri TL (1988) Distribution and activity of picophytoplankton in a brackish environment. In: Jones EBG, Miller JD (eds) Aspects of marine microbiology. Pergamon Press, Oxford, p $129-138$

Aminot A, Chaussepied M (1983) Manuel des analyses chim- iques en milieu marin. CNEXO, Lavoisier, Brest

Anderson DM (1989) Toxic algal blooms and red tides: a global perspective. In: Okaichi T, Anderson DM, Nemoto $\mathrm{T}$ (eds) Red tides - biology, environmental science and toxicology. Elsevier, New York, p 11-16

Balech E (1985) The genus Alexandrium or Gonyaulax of the tamarensis group. In: Anderson AD, White AW, Baden DG (eds) Toxic dinoflagellates. Elsevier, New York, p $32-38$

Blackburn SI, Hallegraeff GM, Bolch CJ (1989) Vegetative reproduction and sexual life cycle of the toxic dinoflagellate Gymnodinium catenatum Graham from Tasmania, Australia. J Phycol 25:577-590

Boni L, Mancini L, Milandri A, Poletti R, Pompei M, Viviani R (1992) First cases of diarrhoetic shellfish poisoning in the Northern Adriatic Sea. In: Vollenweider RA, Marchetti R, Viviani R (eds) Marine coastal eutrophication. Elsevier, Amsterdam, p 419-426

Bravo I, Reguera B, Martinez A, Fraga S (1990) First report of Gymnodinium catenatum Graham on the Spanish Mediterranean coast. In: Granéli E, Sundström B, Edler L, Anderson DM (eds) Toxic marine phytoplankton. Elsevier, New York, p 449-452

Delgado M, Estrada M, Camp J, Fernàndez JV, Santmarti M, Lletì C (1990) Development of a toxic Alexandrium minutum Halim (Dinophyceae) bloom in the harbour of Sant Carles de la Ràpita (Ebro Delta, northwestern Mediterranean). Scientia mar 54(1):1-7

Delmas D, Herbland A, Maestrini SY (1992) Environmental conditions which lead to increase in cell density of the toxic dinoflagellates Dinophysis spp. in nutrient-rich and nutrient-poor waters of the French Atlantic coast. Mar Ecol Prog Ser 89:53-61

Estrada M, Sanchez FJ, Fraga S (1984) Gymnodinium catenatum (Graham) en las rias gallegas (NO de Espana). Inv Pesq 48:31-40

Fraga S, Anderson DM, Bravo I, Reguera B, Steidinger KA, Yentsch CM (1988) Influence of upwelling relaxation on dinoflagellates and shellfish toxicity in Ria de Vigo, Spain. Estuar coast Shelf Sci 27:349-361

Fraga S, Reguera B, Bravo I (1990) Gymnodinium catenatum bloom formation in the Spanish Rias. In: Granéli E, Sundström B, Edler L, Anderson DM (eds) Toxic marine phytoplankton. Elsevier, New York, p 149-154

Giacobbe MG, Crisafi E, Maimone G (1991) Outbreaks of Dinophysis sacculus: a setback for aquaculture. In: De Pauw N, Joyce J (eds) Aquaculture and the environment. European Aquaculture Society, Dublin, p 118-119

Giacobbe MG, Genovese L, Maimone G (1993) Investigations on microalgae of Italian waters for starting aquaculture projects. In: Barnabé G, Kestemont P (eds) Production, environment and quality. European Aquaculture Society, Ghent, p 563-568

Giacobbe MG, Maimone G (1991) Dinophysis sacculus outbreaks in a brackish area of Sicily (Italy). Red Tide Newsletter 4(1):3

Giacobbe MG, Maimone G (1994) First report of Alexandrium minutum Halim in a Mediterranean lagoon. Cryptogamie Algol 15(1):47-52

Giacobbe MG, Maimone G, Azzaro F (1992) Distribuzione del fitoplancton in un'area salmastra della Sicilia Nord-Orientale. Giorn Bot Ital 126(3-4):531-547

Holm-Hansen O, Lorenzen CJ, Holmes RW, Strickland JDH (1965) Fluorometric determination of chlorophyll. J Cons perm int Explor Mer 30:3-15

Ishimaru T (1988) Cultures of Dinophysis fortii and Dinophysis acuminata with the cryptomonad Plagioselmis 
sp. In: Proc Japan Assoc Mycotoxicology, IUPAC88/ ICPP88, 1

La Ferla R, Crisafi E (1991) Preliminary study on vertical distribution of microorganısms in the Bannock Basin waters (Eastern Mediterranean Sea). Mar Ecol Prog Ser 75 : $309-311$

Maestrini SY (1991) The French 'National programme on harmful marine algal blooms' In: Park JS, Kim HG (eds) Recent approaches of red tides. Kyongsangnam-do, NFRDA, p 25-60

Magazzù G (1988) Condizioni oceanografiche e biologiche e concentrazione degli idrocarburi nel Canale di Sicilia
(Campagna dell'ottobre 1987). Relaz Int Dip Biol Anim Ecol Mar, Università di Messina

Millero FJ, Poisson A (1981) International one-atmosphere of state of seawater. Tech Pap mar Sci 38:19-84

Strickland JDH, Parsons TR (1972) A practical handbook of seawater analysis. Fisheries Research Board, Ottawa

Taylor FJR (1992) The taxonomy of harmful marine phytoplankton. Giorn Bot Ital 126(2):209-219

Usagawa T, Nishimura $M$, Itoh $Y$, Uda T, Yasumoto $T$ (1989) Preparation of monoclonal antibodies against okadaic acid prepared from the sponge Halichondria okadai. Toxicon $27(12): 1323-1330$ 